DOI: $10.15503 /$ jecs20152.122.138

\title{
THE UNWANTED PAST AND URBAN REGENERATION OF COMMUNIST HERITAGE CITIES. \\ CASE STUDY: EUROPEAN CAPITALS OF CULTURE (ECOC) RIGA 2014, PILSEN 2015 AND WROCLAW 2016
}

\author{
Corina TURŞIE ${ }^{11}$ \\ West University of Timisoara, \\ (9) $\odot \Theta \Theta$ \\ 4 V. Parvan Blvd., 300223, Timisoara, Romania \\ corina.tursie@e-uvt.ro
}

\begin{abstract}
Within the ECoC programme, it has been argued that the European dimension is most visible when the candidates reflect their own history as a part of European history, particularly when hinting at their involvement with the major ideologies of twentieth century, such as National Socialism or Communism. ECoC is about cities re-inventing their identities, re-narrating their history in a European context. But how should ex-communist cities deal with their unwanted past and narrate it in order to fit into the European dimension of the project? The focus of this investigation is on three ex-ECOCs from ex-Communist Europe, chosen for several reasons: geographical position (Central, Eastern/Northern European countries, ex-communist past, new membership of the European Union (since 2004), the year of holding the title (the two ECoC selection criteria exist since 2010). Using qualitative content analysis on a set of documents (application books, official web pages and ex-post evaluations) the study will offer an analysis of cities' politics of memory and urban regeneration strategies.
\end{abstract}

Keywords: unwanted past, image, urban regeneration, culture, European

\section{INTRODUCTION}

\footnotetext{
"A narrative tying Europe's distant and recent past to the present and providing a vision for the future is essential. (...) Europe is a source of inspiration from the past, it is emancipation in the present, and an aspiration towards a sustainable future.

Europe is an identity, an idea, an ideal"
}

(European Commission, 2014, p.1)

The concept of urban regeneration has received growing attention within the academic community and among policy makers (Florida, 1992; Bianchini, Parkinson, 1993; Porter, 1995; Zukin, 1995; Hall, Hubbard, 1998; Garcia, 2004; Hemphill,

11 Acknowledgement: This work was supported by the strategic grant POSDRU/159/1.5/S/140863, Project ID 140863 (2014), co-financed by the European Social Fund within the Sectorial Operational Program Human Resources Development 2007 - 2013. 
Berry, McGreal, 2004; Miles, 2005; Miles, Paddison, 2005; Evans, 2005; Grodach, Loukaitou-Sideris, 2007; Sacco, Belssi, 2009; Gonzales, 2011; Sacco, Ferrilli, Blessi, 2013; Pares, Costa, Blanco, 2014; Uldemolins, 2014). The renewal of urban areas was associated with cultural policies. Within the post-industrial world, under the impact of globalization, ideas of using culture as an instrument for city economic growth have become an intrinsic part of cities' development strategies, in order to consolidate their competitive position. Starting in the 80's, culture led urban regeneration strategies obtained a central position in urban public entrepreneurship. Even the meaning of culture itself was redefined, from the idea of a representation of values, symbols and lifestyles, towards that of "a resource able to solve political and socioeconomic problems, including those of a city" (Miles, Paddison, 2005, p. 834).

Cşşulture evolved rapidly on the local and regional public policies agenda, but also at the European level. 1985 was the starting point of the European Union's (EU) European Capital of Culture Programme (ECoC). It was initially called City of Culture, and it was an award offered each year to a different city, coming from another EU country, with the purpose to "bring the people of the Member States closer together" (Council Resolution No. 85/C 153/02). Culture was seen as a useful tool to solve Europe's growing social and political problems, caused by the first waves of enlargement and the socio-economic disparities they brought. Besides the initial economic integration project, the EU soon acknowledged the lack of common identity grounds for interaction and solidarity among Europeans. Europe 'in search of its soul' was the primary goal of the City of Culture initiative, because, paraphrasing Jacques Delors, "nobody can fall in love with the Common Market" (Monti, 2012, p. 12). The discourses of European identity and cultural identity, as common grounds to build solidarity, may have been introduced in the 80s to compensate for economic disparities and democratic deficit. Soon after, the first provisions regarding culture were officially introduced into the Maastricht Treaty.

ECoC's legislative framework has changed several times since its origins: objectives were added, as well as selection criteria and a chronological lists of countries assigned to hold the title. According to the current legislation, the purpose of the ECoC Programme is "to highlight the richness and diversity of European cultures and the features they share, as well as to promote greater mutual understanding between European citizens" (European Parliament and of the Council, Decision No $1622 / 2006 / E C)$. It is an internal national competition, and applications must include a cultural programme with a European dimension, based principally on "cultural cooperation" (European Parliament and of the Council, Decision No 1622/2006/EC).

The 2006 EU Decision introduced for the first time criteria of selection for competing cities: the European dimension and City and citizens. The explanation of criteria do not offer many clarifications: As regards the European Dimension, the programme shall: "(a) foster cooperation between cultural operators, artists and cities from the relevant Member States and other Member States in any cultural sector; (b) highlight the richness of cultural diversity in Europe; (c) bring the common aspects of European cultures to the fore" (European Parliament and of the Council, Decision No 1622/2006/EC). And as regards City and Citizens the programme shall: "(a) foster the participation of the citizens living in the city and its surroundings and 
raise their interest as well as the interest of citizens from abroad; (b) be sustainable and be an integral part of the long-term cultural and social development of the city" (European Parliament and of the Council, Decision No 1622/2006/EC).

The long term development of cities became the desired output of the $\mathrm{ECoC}$ Programme, as "cities recognized that the designation was a marketing opportunity to improve their image on a national and European scale and constituted a sort of regeneration tool" (Cogliandro, 2001, p. 8). This opportunity was even more appealing for cities coming from ex-communist countries, after they became eligible to hold the title. At the same time, along with the accession of new EU Member States, the European dimension criterion was being put to a challenge. On one hand, the ECoC Programme was seen as a tool aimed at influencing the cultural unity of a renewed Union, where new Member States had the opportunity to bring to the front their culture and to feel as equals with the older Member States. But on the other hand, it was a real challenge for cities coming from peripheral European positions, ex-non democratic countries, to overcome their inferiority complexes of belonging to old or new Europe, and to highlight their European identity dimension and their contribution to the richness and diversity of European cultures.

Following the positive evaluation by the European Commission of Linz ECoC (2009), in its honest demarche of acknowledging its National-Socialist history as a part of its identity, other $\mathrm{ECoC}$ cities have aimed to link their darkest and unwanted past to the idea of a European dimension in an attempt to make peace with their history. The way cities choose to narrate their past is of great importance. It has been argued that "the European dimension is most visible when the ECoC candidates reflect their own history as a part of European history, particularly when hinting at their involvement with the major ideologies of the nineteenth and twentieth century, such as National Socialism, Communism and colonialism" (Immler, Sakkers, 2014, p. 16).

The importance of these official narrations of the past, and their cathartic and unifying potential, was recently acknowledged by the EU. In the context of the economic crisis and of 2014 European elections, the European Parliament and the Commission launched in april 2013 a project called A new Narrative for Europe, consisting in a series of public debates meant to give a voice to prominent cultural and intellectual personalities. Their task was to articulate a new story for Europe, highlighting its common values and preventing against the danger of populist and nationalistic discourses. The output of the project was a document called The Body and Mind of Europe. Its main line of argument stated that European history consists of a series of "splendors and miseries", marked by three main trials: the end of the Second World War, the fall of the Iron Curtain and the burst of the economic crisis in 2008. Moreover, overcoming them, made Europe's narration evolve until present. The solution proposed for the current situation was a New Renaissance, a cosmopolitan one, using culture as "a major source of nourishment and supply for Europe's social and political body" (European Commission, 2014, p. 3). Urban centers are identified as being the right place to produce this New Renaissance:

"Europe as a political body needs to recognize the value of cultural heritage, both tangible and intangible. Looking back, Europe's heritage was forged not only 
across generations, but also across communities and territories. (...) It is a powerful instrument that provides a sense of belonging amongst and between European citizens. To trigger this potential, Europe as a political body needs to develop a new cosmopolitanism for its citizens that includes dynamic and »creative urban environments and healthy competition between cities«. European cities should become more than urban centres; they should strive to become capitals of culture, increasing the quality of life of all Europeans" (European Commission, 2014, p. 4).

In this paper I argue that the ECoC Programme is a big opportunity, especially for cities coming from ex-communist countries, to produce for themselves a new official narration. Their inferiority complexes of coming from totalitarian regimes, or having young democracies and poor economic condition, can be ovecome especially with the help of the EU's cultural initiatives. Within this process cities are re-inventing their images and they are re-narrating their past in a European context, to which they belong. The content of these narrations is of course, a challenge, and it is part of cities creativity, given the fact that the ECoC Programme is still, a competition.

For the purpose of this paper I consider, following a social constructivist line of argument (Searle, 1995; Adler, 1997; Wendt, 1999) that the official memory of a city's past is a social construct, a narration. Cities administrations, or in this case, the Associations managing each $\mathrm{ECoC}$, are in the position of proposing and controling the narrations of the past, through politics of memory. Their role is to "redefine collective identities and to find ways to deal with the largely unwanted communist past" (Baločkaitè, 2012, p.41). They are actually negotiating a city's identity: what must be remembered, what should be forgotten, and what resists forgetting. The theme of identity is closely linked with the issues of heritage. Defined as "the contemporary uses of the past" (Graham, Ashworth, Tunbridge, 2000), heritage can be an identity tool. Through different heritage sites "tourists are being told the national story, presented to affirm and reinforce national identity and self image" (Light, 2000, p. 159). The Communist heritage, whether tangible (monuments, infrastructure, living districts, industrial sites) or intangible (street names, living habits, patriotic songs) represents an unwanted past and denounced political regime. Choosing to use some items of this heritage in the present or to regenerate them for cultural or touristic purposes is an action with deep symbolic meanings, constituting a city's symbolic landscape. Post socialist transformation involves a complex remaking of place identity at a range scale, to legitimize new political and economic trajectories and further European integration. The ECoC Programme is an example of remaking cities' identity within a European context.

Against this background, this article endeavours to find out what narratives are being created by ex-communist ECoC cities. Three lines of content are being followed: city identity and European dimension; images of the past; and main regeneration projects. In other words, a few questions motivate this research: how are cities from ex-communist countries defining their own European identity, in thier official Bids, in order to win the ECoC title? What image of thier past they are presenting? How are they narrating their totalitarian past? What are their main symbolic regeneration projects? How are these cities viewing their contribution to the richness and diversity of European cultures? 
The focus of this investigation is on three past, current and future ECoCs from Latvia - Riga 2014, Czech Republic - Pilsen 2015 and from Poland - Wroclaw 2016. I have chosen these cities for three reasons: membership of the EU (all of them are new Member States), ex-totalitarian past of the countries and date of holding the title (after 2010 - the introduction of the two selection criteria). Methodologically, this article drawns on document analysis, including ECoC official legislation, the Bid books of Riga 2014, Pilsen 2015 and Wroclaw 2016, their official web pages, ECoC 2014-2016 monitoring reports (preselection reports, first and second monitoring reports, final selection panel reports).

\section{THEORETICAL FRAMEWORK}

Since the collapse of communist regimes, the countries of Central, Eastern and Northern Europe have been attempting to redefine their national identity. This project involves, as we can assume, the contestation and rejection of identities created during communism, including the desire to deny or erase the communist past. City administrations have followed a similar demarche of changing the city's symbolic landscape. Craig Young and Sylvia Kaczmarek (2008) distinguished three strategies of remaking place identity: the de-communization, the return to the pre-communist Golden Age and the Westernization/Internationalization of the city. Versions of the first two received much scholarly attention.

Most of the literature focuses on the process of decommunization of cities - the erasure of the socialist past by the removal of the cultural landscapes of socialism, particularly through the destruction of socialist-era statues, changes in public holidays, and renaming of public spaces. Public places are charged with symbolic content and they represent lieux de mémoire "where memory crystallizes and secrets have occurred at a particular historical moment" (Nora, 1989, p. 7). Monuments, memorial plaques and street names are the most important markers of urban landscape; they "contribute to the semiotic presence of the governing ideology, since they provide the city architecture with a special symbolic content" (Banjeglav, 2012). City-texts, such as street names, are the manifestation of political ideologies, of the ruling elite of the time (Palonen, 2010).

According to Pierra Nora, the ideological decolonization of memory is characteristic for countries liberated from a totalitarian or authoritarian regime, "when these nations turn to their traditional memory, once distorted or destroyed by the previous regime" (Sereda, 2009). Following the French sociologist Maurice Halbwachs, all memory is a social construct, whether it is institutionalized (interpretations of the past offered by political elites) or individual. The literature on collective memory generally agrees that each group has its own collective memory, which is the product of power relations in a society: "History renews itself periodically (...). At big historical torments the collective memory has the task of supporting the new social institutions, with everything that can be taken from traditions" (Ricoeur, 2001, p. 482). Paul Ricoeur also argues that the past cannot be simply 'forgotten' and erased from memory, but it is set aside (oubli de reserve) 
and used again when it is needed, when new political orders and elites try to re-introduce certain events into social memory, that former regimes wanted to forget. This means that political elites are in control of the narratives of the past, through politics of memory, which determine what should, and what should not, be remembered from the past.

Obscuring the socialist era and looking back at a pre-socialist Golden Age is another strategy of dealing with the past. The existence of a privileged Golden Age can be identified through examples of commemorations of important past events or the restoration of past monuments. This strategy can be viewed as doing politics with the past, or manipulating the way in which a historical image of an era, or of a city's history, is rearticulated for political reasons. Collective memory is always selective, and by deliberately selecting its content, important outputs can be achieved in terms of identity; by being "an image of the past", collective memory "allows the group to recognize itself throughout the succession of images" (Hallbwachs, 1992, p. 86). The image, with resonance to Ernesto Laclau's discourse theory, is "a caption which would be including certain things and excluding others. This character of inclusion and exclusion through representation or reproduction makes the image explicitly political - it involves choices and redescription that would have larger discursive effects" (Palonen, 2010, p. 3).

Post socialist identity formation involves conflict over the understanding of the past, a "politically mediated process circumscribed by wider debates in post communism concerning the politics of memory and identity" (Light, 2000, p.173) and the way the past is represented in official narratives.

ECoC competition represents an identity laboratory. It allows city's administrations (represented by the Associations managing the Bid), by writing the city's Bid Book, to build a new image for the city and to create new official narrations of cities' identity. To sum up, this article investigates the content of ECoC cities official identity narrations, in order to identify the formulation of the European dimension of their identity, the images of their past they appeal to and the lieux de mémoire they want to regenerate.

\section{CITY IDENTITY AND THE EUROPEAN DIMENSION}

Building a new image for a city as a European Capital of Culture involved a constant reference to the connection between the city and Europe. The European dimension was described in the analyzed Bid Books using two strategies: first of all, using European themes to describe the city and its Cultural Programme and secondly, cooperating with European artists, cultural organizations, or NGO networks.

Regarding the European themes, the geographical position of the city in relation to the European continent was the starting point of this image creating process. Even the most marginal European cities tried to present their position as a more central one (or the centre of a certain region, in accordance with the Capital statute), as a significant liaison between different European areas, or at least, as a 
potential metropolis aspiring towards its Western counterparts. Riga 2014 is "a cultural metropolis, a European suburb, a point »between Russia and the West", a harbor town" (Riga, 2009, p. 12), "most significant Baltic transit point" (Riga, 2009 , p. 27). Pilsen is "a city which has the right geographical location to become a bridge between »old « and »new « Europe" (Pilsen, 2010, p. 15). Its flaws can be overcome by smart growth, providing "a durable and sustainable change of a provincial city into a real European cultural metropolis" (Pilsen, 2010, p.15). Wroclaw 2016 speaks honestly about "Poland's double peripherality - Polish metropolises being peripheral to Europe's; small towns being peripheral to large cities" (Wroclaw, 2011, p. 16). But this position can be overcome with dynamism "Wrocław is a city 'on the road'. Our aim is to create a modern European metropolis (....) joining the »European premier league «" (Wroclaw, 2011, p. 4).

The multicultural character of cities and of their goals is a theme to be found at the very beginning of each Bid Book. Riga 2014 is "a bilingual society, a city with rich cultural traditions" (Riga, 2009, p. 12). Its purposes are "to show the »diversity of European culture " and encourage intercultural dialogue" (Riga, 2009, p. 17). For Pilsen, "the ECoC 2015 project is a unique opportunity to »strengthen the intercultural dialogue « at a global level" (Pilsen, 2010, p. 34). "The dialogue of the cultures of European people" is also the goal of Wroclaw (2011, p. 8).

The role of culture in shaping the long term of the development of the city is another key European value reflecting the European dimension of ECoCs. Riga (2009, p. 15) sees creativity as "a resource for the future" , and culture as "a creator of added value, creative industries and all other fields and the driving force of sustainable development of the city" (Riga, 2009, p. 19). Pilsen 2015 assumes "to use culture as a »catalyst for creativity and innovation «" (Pilsen, 2010, p. 34). Wroclaw (2011, p. 7) considers that the city has "an important role in building the modern European knowledge society, with culture as one of the key pillars of stability, cohesion, and growth". Using an extensive approach of culture "high, popular, and folk" Wroclaw's Bid (2011, p. 4) argues the educational role of culture, which "has the power of cementing society and fostering all aspects of its identity. Culture helps to bring out what is common and unifying; Above all, it teaches tolerance and creativity".

The other two cities were also trying to define culture in an extensive manner, in order to provide massive participation in culture, both for artists and for the public. Pilsen (2010, p. 34) sees culture "in a broad sense", aiming "to provide significant support to the sector of the so-called »subculture « and to »open the space " for potential artists and organisers who have been more in the »background «". Wroclaw presents itself as "Poland's fastest growing cultural, academic and economic metropolis" (Wroclaw, 2011, p. 3). Its success is allegedly to be found in Wrocław residents' sense of citizenship: "their willingness to participate in the life of the city and the state, as well as their sense of responsibility for the future of the young generation" (Wroclaw, 2011, p. 3). In the case of Riga, one of the three basic principles of its Programme is Expansion of borders, understood as the "broadening of the understanding of the notion of culture through close interaction with other fields" (Riga, 2009, p. 19). In its Bid Book, Riga also acknowledges the conceptual connection between culture-participation-identity. Par- 
ticipation is seen as "the basis of cultural development, which would interweave and link civil responsibility, identity, creation, intercultural dialogue and festive atmosphere" (Riga, 2009, p.17).

The bottom up rhetoric of the project is also an expression of the European dimension of the cities. The whole ECoC programme is meant to be a bottom up integrative approach using culture as a complementary policy tool, meant to compensate the failures of supranational market and monetary policies, such as socio-economic disparities. Cities are given the opportunity to be vehicles of local, regional, national and European integration. The bottom up approach consists in the fact that cities propose Cultural Programmes having several well defined guidelines. Within these guidelines, the Programmes are being filled with projects selected upon an open call procedure, available to all citizens, artists, NGO's and cultural operators. Pilsen 2015 referred explicitly to its bottom up path as a strategy "for addressing the broadest range of citizens who gradually show their will to change things". The "bottom up" approach "shows that culture is the real engine of society, after all the cultural and creative industries sit among the few not affected by the economic crisis" (Pilsen, 2010, p. 67). Wroclaw 2016 considers this approach as an "innovation", meant to "support initiatives of culture creators and citizens" and to solve "the crisis of society" by building "a conscious, active and creative society" able to "combat all forms of exclusion" (Wroclaw, 2011, p. 34).

There are also other classical European themes which were introduced by cities in their Cultural Programmes as major "guideline themes" (see Table 1. for an extensive list). First of all, social services, minorities (theme Transit and minorities Pilsen 2015, Beauty in Sight, Intimate Beauty, Wroclaw 2016; with the exception of Riga, who was criticized by the Selection panel for not representing the Russian minority); secondly, ecologic themes (Forces of Nature - Power of Culture, Wroclaw 2016, Survival Kit, Riga 2014, Stories an sources, Pilsen 2015); thirdly, the importance of nature in urban space (Forces of Nature - Power of Culture, Wroclaw 2016; fourth, the role of education, innovation and technology in everyday life (Art and Technology Pilsen, 2015, Beauty in Cyberspace, Wroclaw 2016, Survival Kit, Road map, Riga 2014); and last, European theme, the importance of a healthy lifestyle (Survival Kit, Riga 2014; Intimate Beauty, Wroclaw 2016).

Table 1. ECoC - thematic guidelines, slogan and concept.

\begin{tabular}{|l|l|l|l|}
\hline ECoC & Riga 2014 & Pilsen 2015 & Wroclaw 2016 \\
\hline \multirow{4}{*}{$\begin{array}{l}\text { Thematic } \\
\text { Guidelines }\end{array}$} & Thirst for the Ocean & Art and Technology & Opening up Spaces \\
\cline { 2 - 4 } & Freedom Street & Relations and Emotions & Beauty in Site \\
\cline { 2 - 4 } & Survival Kit & Transit and minorities & Intimate Beauty \\
\cline { 2 - 4 } & Road map & Stories and sources & Beauty in Cyberspace \\
\cline { 2 - 4 } & Riga carnival & & $\begin{array}{l}\text { Forces of Nature - Power of } \\
\text { Culture }\end{array}$ \\
\cline { 2 - 4 } & Amber Vein & Open up! & Spaces for Beauty \\
\hline Slogan & Force Majeure & $\begin{array}{l}\text { From totalitarism to } \\
\text { Creativity }\end{array}$ & Metamorphoses of Culture \\
\hline Concept & Kultu[rix] & & \\
\hline
\end{tabular}

Source: author's compilation of information from ECoC Bid Books. 
European cooperation with foreign artists, cultural operators, networks of NGO's and other European cities is a mandatory feature of ECoC applications. Riga 2014 stated its belonging to Eurocities Network. Pilsen 2015 assumed to "support of mobility of artists and organisers at all levels", to "help distribute the image of an active and creative Europe", and to "strengthening ties with the rest of Europe" (Pilsen, 2010, p. 36). Wroclaw mentioned in its application the European exchange networks in which it already plays an active role, such as Eurocities, Metrex, Eurofuturoscope and the Hanse. It also proposed the creation of the Phoenix Cities network. This network would be focused on "identifying historical paths that cities have followed to transform and establish their identities after suffering painful injuries inflicted by history or nature" (Wroclaw, 2011, p. 30).

We have seen a lot of similarities between the three Bid Books and the homogeneity of European themes used to express their European identity. Certainly, the most creative part of the Bid Books refers to identifying the need of cities to win the title, connected with the concept and slogan of their Bid. The following analysis allows us to get a better representation of each city's image in relation to its past. It also offers important input about ECoCs' vision concerning their contribution to Europe's culture and future integration.

\section{IMAGES OF THE PAST, LEGACY FOR THE FUTURE}

One of the big opportunities brought by ECoC Programme is the possibility of cities to take an honest radiography of their past and present problems and challenges, and to propose solutions facilitated by holding the ECoC title. Moreover, cities are warmly recommended to use the ECoC as "the opportunity not only to highlight the bright parts of their history, but also to tackle some of the more controversial aspects of it" (Report on the $2^{\text {nd }}$ Monitoring and Advisory Meeting for the ECoC 2015, 2014, p.10)

In line with this recommendation, Wroclaw 2016 considered that one of the innovations of its project is the fact that it "provides diagnoses. We do not shy away from talking about the crisis of society" (Wroclaw, 2011, p. 34). According to its Bid, Wroclaw needed to win the title because culture, and its innovative development potential, is the only resource left for postindustrial Wroclaw, when the traditional industrial ones have gone: "Our growth has been possible thanks to quantitative reserves; they have, however, been largely exhausted. The next stage in the city's growth must be based on a qualitative change. This must involve mobilizing civic, social, professional, and creative activity" (Wroclaw, 2011, p. 7). After twenty years of transition, Wroclaw witnesses the perpetuation of former communist regime ties and values, lack of mutual trust, social inequalities, emigration of young Poles and lack of participation in culture.

Today's image of Wroclaw bears the scars of the past. Two moments from Wroclaw's history inspired its ECoC slogan and concept. First of all, a dramatic event in the thousand-year history of the city was the complete replacement of population, unprecedented in the history of Central Europe, that took place when the Second 
World War had ended and German Breslau was turning into Polish Wrocław. Back then, it "has laboriously rebuilt its identity out of the myth of Lwów, with pioneering efforts" (Wroclaw, 2011, p. 3). This part of the city's history inspired the concept of its ECoC candidature: Metamorphoses of culture, understood as past and present dynamic of changes in the cultures of Europe peoples. The metamorphoses of the past refers to the events following the Second World War, when Wroclaw became a "laboratory in which Polish culture imported from the Eastern Borderlands flourished, on material heritage left behind by the Germans and has undergone a metamorphosis into a unique cultural formation" (Wroclaw, 2011, p. 9). The metamorphoses of the present refers to today's Wrocław, which still remains "a cultural laboratory", but the identity of its residents is challenged by new phenomena: "globalization, immigration, EU enlargement, digital era" (Wroclaw, 2011, p. 9). Under continuous metamorphoses, Wroclaw is a city with multiple identity. Its inhabitants have transformed, the post WWII foreign city into their own, so that Wroclaw "has become a laboratory of identity: the Europeans living in the city had to navigate a difficult path to create their own identity" (Wroclaw, 2011, p. 21). Wroclaw's multiple identities are used in the Bid as a description of its European dimension and its international character: it reflects the cosmopolitan diversity characteristic of the entire European continent. Moreover, Wrocław's past makes the city "a reduced model of Europe (...) citizens of Wrocław, descendants of people who, having lost their native lands made a foreign city and region their new home" (Wroclaw, 2011, p. 22). In this context, the bid touches a sensitive point related to migration from Poland to Western Europe and its implications the fact that over two million Poles recently left the country, has had numerous consequences: "by their absence, they have influenced the dynamics of social change in Poland; through their presence - too numerous and too visible in the opinion of some - they have been influencing societies in other European countries" (Wroclaw, 2011, p. 21). The city's contribution to the future of European integration consists in the availability to share its "experience of dealing with the difficult task set off by building a new identity for the city" (Wroclaw, 2011, p. 22).

The other scar from the city's past is its communist history, which also allows the city to express its past contribution to European integration. Wrocław of the 1980s assumed a new meaning, becoming a real fortress of Solidarity, the Polish social movement that contributed to the self-liberation of Eastern Europe and the reunification of Germany. The role played by Wroclaw in the organization of Solidarity is probably the main component of the European dimension of Wroclaw's past identity. The movement has been the strongest in two cities: Gdansk and Wroclaw, but it is in Wroclaw that "the diversity of form of protest, methods of its organization, and the range of repressions during the martial law were greatest" (Wroclaw, 2011, p. 3). The phenomenon of Solidarity "opened Poland's road to Europe", but also "helped to shape the new Europe" (Wroclaw, 2011, p. 7). This is the major legacy of Wroclaw for Europe and the mark of its European/international character. Wroclaw's communist past inspired the slogan of its ECoC candidature: Spaces for beauty, with the supplementary explanation: "Beauty of freedom, freedom of beauty". Wroclaw's implication in the anticommunist revolt was a manifestation of refusal to accept violations of human rights and restrictions of civil 
liberties by the communist regime, longing for a different life, and first of all, for freedom. Facing unexpected disappointments of democratic life, the aim of the ECoC year is "to create open, dynamic, and friendly spaces that will serve the human craving for communion with art and culture (...). To establish the presence of beauty in public life and in daily habits (...) to restore the beauty of democracy" (Wroclaw, 2011, p. 14-15).

Pilsen 2015 also performs radiography of its problems. Belonging to an ex-communist country, Pilsen experienced in the past twenty years, the process of economic transformation, but it considers that the process of spiritual transformation was ignored. There are "many problems, not discussed, simmering below the surface, from which a strong desire for the inner transformation of society grows" (Pilsen, 2010, p. 43). Pilsen wanted to share with Europe its inner transformation of society, reflected in the concept of its Bid is: From Totalitarism to creativity Pilsen presents itself as a "bridge from totalitarian regime to creativity" (Pilsen, 2010, p. 15). Totalitarian heritage represents for Pilsen "post-communist institutions, corruption, nepotism and politicking", while its desire is to have "real policy in the interest of public welfare". The city's hope is represented by the new generation "skilled in languages, educated in the new democracy, with a wider outlook and hopefully with a perception of their coexistence within the European community" (Pilsen, 2010, p. 15)

Overcoming the heritage of old totalitarian regimes, inspired its slogan: Pilsen, open up! It is about "opening from within every one of us and about overcoming the closed character of Czech society. This character is caused by the deep scars of country's historical experience with a totalitarian regime" (Pilsen, 2010, p. 17). And Czech society was under the pressure of two totalitarian regimes (Nazism, from 1938, followed by Communism from 1948).

The connection of Pilsen with its totalitarian past is presented in its Bid Book under the theme Relationships and emotions, a theme of personal, national and European identity. It involved organizing a series of dialogues and artistic events, as another way of dealing with past. Several themes were approached, such as the imprint of twentieth century history in human souls, the reflections of Czech society on European topics, or opening Czech society towards Europe. One of the projects worth mentioning is Czech Culture under the Oppression of Two Regimes (1938-1953), an exhibition of visual arts based on the main historical events of the last forty years, reflecting the influence of both totalitarian regimes on the destinies of people. Another example is Freedom of Expression and the Power of Totalitarianism a mix musical-literary evening consisting in reading works written in the extreme conditions of the totalitarian prisons.

The slogan Pilsen, open Up! has also another meaning, as the Bid admits it. In Czech, the name of the city is colloquially used for designating the famous beer, which is what the double sense open up is based on. This new sense of the slogan is in close connection with the need of the city to win the title: the city's name has a reputation, it gave its name to one of the most famous beers in the world, but it is peripheral on the cultural map of Europe. The city aims that, following the ECoC year, "the word Pilsen evokes excitement not only with beer fans, but also with 
cultural tourists and the general public both in Europe and outside our continent" (Pilsen, 2010, p. 15).

Riga 2014 (2009, p. 50) presents its history as a "space for collisions, where echoes of global historical events can be found. Over the entire course of the twentieth century Riga has found itself in postwar-prewar relationships or loser-winner relationships". By celebrating the centenary of the First World War, Riga 2014 wanted to show that precisely that historical period was the starting point of Riga losing its past prestige, which should be recovered through the ECoC Programme: "In 1914, Riga was one of the group of cities that formed part of the indisputable European prestige, which, together with the First World War, Europe lost, leaving indelible consequences in the consciousness of Europeans" (Riga, 2009, p. 50). Re-discovering "the unknown Riga, industrial Riga, the third largest industrial centre of Russia in the early twentieth century" (Riga, 2009, p. 79) is a strong aim of the city Bid.

The need of Riga to recover its Golden Age, its pre-war statute, and the unique opportunity for this provided by the ECoC Programme, is expressed by the concept of the Bid: Force Majeure. Force Majeure is "a catalyst and provoker of cultural events (...) culture can become an invincible force that works as an instrument of salvation, a survival kit, a springboard for new and bold ideas, which helps transform the world and allows us to look at it from a different angle" (Riga, 2009, p. 31).

In order to express the past prestige of the city and its importance for the European history, Riga 2014 goes beyond the twentieth century and appeals to much older layers of its identity. The Amber Vein programme anchors the Baltic Sea Area to the beginning of civilizations. Historians refer to the Amber Route as belonging to the 'highest league' of ancient European trade routes, where amber was mentioned as a valuable currency since prehistoric times. Precisely the Gulf of Riga has been the starting point for an amber trading network that spanned the entire European continent and beyond. All civilizations (Roman, Greek, Egyptian) desired the 'sun-stone' and "the amber trade could be seen (quite legitimately) as the first example of a pan-European market, a kind of European Union (only the trade in flint occurs earlier in human history)" (Riga, 2009, p. 106). By this programme, Riga wanted to show that even though only its implication in East-West European relations was mostly highlighted in various time periods, the role of Riga and the rest of Latvia in the implementation of the Northern-Southern axis should not be forgotten. In the application for Riga ECoC 2014, the modern Amber Route signifies a new cultural cooperation network between European cities located in the ancient amber trade route in a new, interdisciplinary partnership. This is "Riga's and Latvia's investment in world culture and the development of human creativity" ( Riga, 2009, p. 106).

The more recent history of Riga is briefly mentioned in its Bid, and it is described as challenging times that can be overcome by a creative economy as the resource of the future, allowing joint responsibility to emerge. "For twenty years Latvia's history has been characterized by - nationalism - segregation - Europeanization migration - ascent - crisis - joint creation of responsibility. These processes can be considered summary development lines, resulting from privatization, liberaliza- 
tion and structural reform" (Riga, 2009, p. 15). Open society, common trust, desire to cooperate are considered preconditions of creative economy.

By its slogan, Kultu[rix], Riga 2014 (2009, p. 14) transmits the message that it is "a city inseparable from culture". A hybrid of words was produced: Kultu[rix], RIX being the airport's denomination marking Riga on the global map, as "the key to the Riga's cultural space code, encompassing both tradition and innovation, joining the common with the elitist, immersing the local into the global and holding an endless amount of the undiscovered and unknown" (Riga, 2009, p. 12).

Besides narrating their past, the three analyzed $\mathrm{ECoC}$ cities pursued concrete urban regeneration projects. Their symbolic meanings will be discussed in the following part of the article.

\section{SYMBOLIC URBAN REGENERATION PROJECTS}

The contemporary urban public space can be seen as a platform for interaction, with both psychological as well as physical construction of space. It can be viewed as a politicized social construct, which cannot be separated from conflicting social relations that characterized specific societies at different moments in history.

For Riga 2014 (2014, p. 50) "a city is not only made up of buildings and carriageways, but rather by containers of meaning, flows of information, language grids and vectors of varied pressure". The most important container of meaning for Riga 2014 urban space was Freedom Street. It is the name of one of Riga's thematic guidelines, but also an actual street, the axis of the city of Riga, the main street. It received this name at the end of the First World War. Since then has been successively called Large Sand Street, Aļeksandrovskij bulvoar, Petrogradskoje šosse, Revolution Street, Adolf Hitler Strasse, Lenin Street and finally - Freedom Street once more. This street experienced the fact that when a ruling power changes, after a revolution or war, the first thing that power does is to change the names of streets, in a process of writing and re-writing history.

In 2014 the street was revamped to regain its historic names in the form of artistic events along its entire length, above all stressing the invaluable virtue of freedom and democracy. The Freedom Street programme included rituals of regret, truce, commemoration and forgiveness in the form of culture. One of these projects concerned Riga's old factories and manufacturing plants located on Freedom Street, which were evacuated to Russia in 1915, as war was approaching, causing huge losses for Latvian industry and for Riga in particular. In 2014, these former factory territories were transformed into locations for cultural events, especially on war themes.

Freedom Street, within the context of the Riga 2014 (2009, p. 50), "is not just the story of a street. (...) is a symbolic stage, a system of signs, a tale of history and wars", a true lieu de mémoire. Freedom street was the silent witness of all troubled times in Riga's history: First and Second World War, Cold War, Singing Revolution, August 1991 putsch. Prewar and postwar periods "have taken European culture, homes, places, people, generations, stories, memories, monuments and 
spirit, facilitating progress and always - on someone's account. Freedom Street is a stage for both destruction and renewal. Freedom Street continues to be the symbol of power of its time" (Riga, 2009, p. 51). Considering the traumas of the previous generations, a whole century could be erased, as bringing no plus in terms of freedom and democracy: "in a way, for Riga, the First World War ended in 1991" (Riga, 2009, p. 51).

Riga 2014 also invested in two new cultural infrastructure facilities: the National Library and the Contemporary Art Museum, making Riga "the location for new ideas, testimony of excellence, developing types of cooperation forms that would not be possible without these facilities" (Riga, 2009, p. 26). The new National Library was necessary as Riga was also the European book capital in 2014. The events were mixed at the opening ceremony of Riga 2014, when a human chain transported, from hand to hand, the books from the old library building to the new one. Another example is The Book 1514-2014- a special exhibition dedicated to humanity's history in reading, consisting solely of 500 year old books. This can be seen as another attempt of Riga to refer to old and valuable layers of its past.

Historically, Pilsen, has been an industrial city that identified its existence with its industrial production, now facing decline (for example, Škoda engineering plants). According to the Pilsen Bid, its urban image was disturbed by two historical events: bombing of Pilsen by the allied air force at the end of Second World War and the revolution in 1989. Some of the scars of bombing are still visible today in the central part of the city (including Emil Škoda Square). The turn of the $21^{\text {st }}$ century brought another urban problem, associated with the transformation of the economic base of the city: the so called brown fields - unused or underused former factory spaces or military sites. The largest brownfield site is the main Škoda engineering complex, where the revitalization started independently of the ECoC year, giving its industrial significance for Pilsen and the whole country. During the ECoC year this symbol is being used as an association between art and technology. In 2015, the Emil Škoda Square is intended to serve as a platform, for works of art of the creators attending symposiums organised by the Institutue of Art and Design.

In terms of the city's candidature for the ECoC 2015 title, the Světovar brownfield site is significant. The main investment connected with the Pilsen 2015 project is the revitalisation of the Světovar building. The investment consisted of transforming the old brewery into a cultural center - Světovar Cultural Factory (Pilsen, 2010, p. 73). The former Světovar brewery, located in the southeast part of the city, occupies an area of approx. 5 hectares. The building of the brewery was commenced a hundred years ago, however beer production ended as early as in 1933. Since then, the complex has mainly been used for military purposes. From the very outset, emphasis has been placed on preserving the historical brewery buildings, which are "a unique specimen of early twentieth century industrial architecture. They have been listed as cultural heritage sites since 2008" (Pilsen, 2010, p. 208). Pilsen's Golden Age seems to be its era of industrial flourishing of the Skoda Factory and active breweries. Following the example of Světovar brewery complex revitalisation and using the renown of the city related to beer, Pilsen 2015 planned 
to create a network of revitalised breweries, whith the purpose of promoting long-term cooperation with partners from all over Europe.

Wroclaw also proposed in its Bid infrastructure investments, considering that the sustainability of cultural projects after the $\mathrm{ECoC}$ year will be achieved through the construction of new and necessary facilities for cultural institutions, such as the Museum of Modern Art and the National Music Forum. A symbolic regeneration project is called Zachęta, Wroclaw's Guggenheim. It refers to the regeneration of a disused cylindrical air-raid shelter, which was adapted for modern art exhibits. The Zachęta gallery displays works by contemporary local artists. Its outside wall is already used for the display of conceptual art. In 2010, Andrzej Jarodzki's sculpture Train to Heaven was put up nearby. The 25-metre-high sculpture is allegedly "the tallest in Europe" (Wroclaw, 2011, p. 93). Mentioning this fact in the Bid Book can be viewed as an expression of the competitive spirit of Wroclaw and its desire to erase the old-new Europe rhetoric: "as members of the European Union, we want to participate, on an equal footing, in shaping a new European identity (..) as a Europe founded on the ideas of diversity, opportunities, and responsibility" (Wroclaw, 2011, p. 22).

\section{CONCLUSIONS}

The three Bid Books analyzed allowed us to have a good representation of the cities' images, constructed in order to win the ECoC title. In their attempt to fulfill the two selection criteria European dimension and City and citizens we can see that important parts of the Bids' content are similar. All three cities used, in a mandatory manner, themes such as multiculturalism, ecology or digitalization. This aspect makes the entire application to appear like a very technical process, similar to fulfilling a European check list, in order to win the title, living little room for diversity.

This article argues that the most creative part of the Bids, allowing the reader to discover local specificities, is represented by identifying in each Bid the following topics: cities' need to win the title, the shared image of cities' past, their contribution to Europe's future, and symbolic urban regeneration projects. We found out in this way which is the Golden Age of Riga, what is its main lieu de mémoire and how Amber Vein is a forgotten unifying mythology for Europe; we also discovered Pilsen's road from Totalitarism to creativity and the importance of Světovar Cultural Factory for European networking; or how courageous Wroclaw, as a laboratory of identity, can be seen as a reduced model of Europe.

Giving the accent put on extending participation to culture in all three cities, the most important result of holding the title by any of these cities should be, undoubtedly, the development of human capital. To paraphrase Pilsen's Bid Book, "after all, people are the biggest brown fields". Performing a study on official narrations - the representation of city image in ECoC Bid Books- this article is limited to a macro-investigation of city identity - the one built by city administrations; it should be continued with a micro-study, on city identity as perceived by its own citizens. 


\section{REFERENCES}

Adler, E. (1997). Seizing the middle ground: Constructivism in world politics. European Journal of International Relations, 3(3). 319-363.

Baločkaitè, R. (2012). Coping with the Unwanted Past in the Planned Soviet Towns: Visaginas, Tychy and Nowa Huta. Slovo, 24(1). 41-57.

Banjeglav, T. (2012). Memory of War or War over Memory? The Official Politics of Remembering in 1990s Croatia. Vienna: Institute for Human Sciences.

Bianchini, F., Parkinson, M. (Eds.) (1993). Cultural Policy and Urban Regeneration. Manchester: Manchester University Press.

Cogliandro, G. (2001). European cities of culture for the Year 2000: A wealth of urban cultures for celebrating the turn of the century. Bruxelles: Association of the European Cities of Culture of the year 2000, AECC/AVEC.

Council Resolution No. 85/C153/02 from 13 June 1985 regarding the event "European City of Culture", Official Journal, C 153 , 22.06.1985 P. 0002 - 0002. Retrieved from http://eur-lex.europa.eu/legal-content/ EN/TXT/HTML/?uri=CELEX:41985X0622\&from=EN.

Decision No. 1622/2006/EC of the European Parliament and of the Council of 24 October 2006 establishing a Community action for the European Capital of Culture event for the years 2007 to 2019, Official Journal of the European Union, L 304/1, 3.11.2006.

European Commission (2014). A New Narrative for Europe. The Mind and Body of Europe. Retrieved from http://ec.europa.eu/culture/policy/new-narrative/documents/declaration_en.pdf.

Evans, G. (2005). Measure for measure: Evaluating the Evidence of Culture's Contribution to Regeneration. Urban Studies, 42. 959-983.

Florida, R. (1992). The rise of the Creative Class and how it's Transforming Work, Leisure, Community and Everyday life. New York: Basic Books.

Garcia, B. (2004). Urban regeneration, arts programming and major events: Glasgow 1990, Sydney 2000 and Barcelona 2004. The International Journal of Cultural Policy, 10. 103-118.

Gonzalez, S. (2011). Bilbao and Barcelona in Motion: how Urban Regeneration Models Travel and Mutate in the Global Flows of Policy Tourism. Urban Studies, 48. 1397-1418.

Graham, B., Ashworth, G., Tunbridge, J. E. (2000). A Geography of Heritage: Power, Culture and Economy. London: Arnold.

Grodach, C., Loukaitou-Sideris, A. (2007). Cultural development strategies and urban revitalisation. International Journal of Cultural Policy, 13. 349-366.

Hall, T., Hubbard, P. (Eds.) (1998). The Entrepreneurial City: Geographies of Politics, Regime and Representation. New York: John Wiley\&Sons.

Hallbwachs, M. (1992). On collective memory. Chicago: Chicago University Press.

Hemphill L., Berry J, McGreal S. (2004). An indicator-based Approach to Measuring Sustainable Urban Regeneration Performance. Urban Studies, 41. 725-772.

Immler, N., Sakkers, H. (2014). (Re)Programming Europe: European Capitals of Culture: rethinking the role of culture. Journal of European Studies, 14(1). 3-29.

Light, D. (2000). Gazing on communism: heritage tourism and post-communist identities in Germany, Hungary and Romania. Tourism Geographies, 2. 157-176.

Miles, M., (2005). Testing the Rhetoric of Culturally Led Urban Development. Urban Studies, 42. 889-911.

Miles, S., Paddison, R. (2005). The Rise and Rise of Culture-led Urban regeneration. Urban Studies, 42. 833-839.

Monti, M. (2010). A new strategy for the single market at the service of Europe's economy and society. Report to the President of the European Commission José Manuel Barroso. Retrieved from http:// ec.europa.eu/internal_market/strategy/docs/monti_report_final_10_05_2010_en.pdf.

Norra, P. (1989). Between Memory and History: Les Lieux de Mémoire. Representations, 26. 7-24.

Palonen, E. (2010). Creating Communities: The Postcommunist City-Text of Budapest. Transit. Retrieved from http:/ / www.iwm.at/read-listen-watch/transit-online/creating-communities.

Parés, M., Costa, M. M., Blanco, I. (2014). Geographies of governance: How place matters in urban regeneration. Urban Studies, 51. 3129-3146.

Pilsen 2015 (2010). Pilsen, Open up! Retrieved from: http:/ / www.plzen2015.cz/en/sites/plzen2015.cz.en/ files/pilsen_application_en.pdf

Porter, M. E. (1995). The competitive advantage of the inner city, Harvard Business Review, 3. 55-71.

Ricoeur, P. (2001). Memoria, istoria, uitarea [Memory, History, Forgetting]. Timisoara: Editura Amarcord. 
Riga 2014 (2009). Force Majeure. Retrieved from https://www.riga.lv/media/dokumenti/ekg_2009_ book_eng_FIN.pdf

Sacco, P., Blessi, T. (2009). The Social Viability of Culture-led Urban Transformation Processes: Evidence from the Bicocca District. Urban Studies, 45. 1115-1135.

Sacco, P., Ferilli, G., Blessi, T. (2013). Understanding culture-led local development: A critique of alternative theoretical explanations. Urban studies. 1-16.

Searle, J. (1995). The Construction of Social Reality. New York: Free Press.

Selection Panel (2011). Selection of the European Capital of Culture for 2016 in Poland. Final Selection report. Warsaw. Retrieved from http://ec.europa.eu/programmes/creative-europe/actions/documents/ ecoc/2016/panel-poland_en.pdf.

Selection Panel (2009a). Final Report of the Selection Panel following the final selection meeting. Riga. Retrieved from http://ec.europa.eu/programmes/creative-europe/actions/documents/ecoc/2014/ panel-latvia_en.pdf.

Selection Panel (2009b) Designation of a European Capital of Culture for 2014 Pre-selection report. Retrieved from http://ec.europa.eu/programmes/creative-europe/actions/documents/ecoc/2014/ preselection-report-latvia_en.pdf.

Selection Panel (2009c). Designation of a European Capital of Culture for 2015 in the Czech Republic. Selection Panel Pre-selection report, Prague. Retrieved from http://www.mkcr.cz/assets/evropska-unie/ evropske-hlavni-mesto-kultury/Preselection-report-CZ_2015_EN.pdf.

Selection Panel (2010a). Selection of the European Capital of Culture for 2015 in the Czech Republic. Final Selection report. Prague. Retrieved from http://www.mkcr.cz/assets/evropska-unie/ evropske-hlavni-mesto-kultury/Final-Selection-Report_ECOC-2015-CZ_EN.pdf.

Selection Panel (2010b). Designation of the European Capital of Culture 2016. Selection Panel Report on Pre-selection. Warsaw. Retrieved from http://ec.europa.eu/programmes/creative-europe/actions/ documents/ecoc/2016/preselection-poland_en.pdf.

Sereda, V. (2009). Politics of Memory and Urban Landscape: The Case of Lviv after World War II (1). Vienna: Institute for Human Sciences. Retrieved from http://www.iwm.at/read-listen-watch/transit-online/ politics-of-memory-and-urban-landscape.

The Monitoring and Advisory Panel for the European Capital of Culture (2015). Report on the $2^{\text {nd }}$ Monitoring and Advisory Meeting for the European Capitals of Culture 2016. Retrieved from http:/ / ec.europa.eu/programmes/creative-europe/actions/documents/ecoc/2016/second-monitoring_en.pdf.

The Monitoring and Advisory Panel for the European Capital of Culture (2013). Report on the $1^{\text {st }}$ Monitoring and Advisory Meeting for the European Capitals of Culture 2016. Retrieved from http:/ / ec.europa.eu/programmes/creative-europe/actions/documents/ecoc/2016/first-monitoring_en.pdf.

The Monitoring and Advisory Panel for the European Capital of Culture (2014). Report on the $2^{\text {nd }}$ Monitoring and Advisory Meeting for the European Capitals of Culture 2015. Retrieved from http:/ / ec.europa.eu/culture/news/2014/documents/2015-ecoc-2nd-monitoring-report-final_en.pdf.

The Monitoring and Advisory Panel for the European Capital of Culture (2012). Report on the $1^{\text {st }}$ Monitoring and Advisory Meeting for the European Capitals of Culture 2015. Retrieved from http://ec.europa.eu/culture/news/2014/documents/2015-ecoc-2nd-monitoring-report-final_en.pdf.

The Monitoring and Advisory Panel for the European Capital of Culture (2013). Report on the $2^{\text {nd }}$ Monitoring and Advisory Meeting for the European Capitals of Culture 2014. Retrieved from http:/ / ec.europa.eu/ programmes/creative-europe/actions/documents/ecoc/2014/second-monitoring-report_en.pdf.

The Monitoring and Advisory Panel for the European Capital of Culture (2011). Report on the $1^{\text {st }}$ Monitoring and Advisory Meeting for the European Capitals of Culture 2014. Retrieved from http:/ /ec.europa. eu/programmes/creative-europe/actions/documents/ecoc/2014/first-monitoring-report_en.pdf.

Treaty establishing the European Community (Maastricht Treaty, Amsterdam consolidated version) (1997). Official Journal, 340. 0245.

Ulldemolins, J. R. (2014). Culture and Authenticity in Urban Regeneration Processes: Place Branding in Central Barcelona. Urban Studies, 51-14. 3026-3045.

Wendt, A. (1999). Social Theory of International Politics. Cambridge: CUP.

Wroclaw 2016 (2011). Spaces for beauty revisisted. Retrieved from http://www.wroclaw.pl/files/ESK/ application_revisited_en.pdf.

Young, C., Kaczmarek, S. (2008). The Socialist Past and Postsocialist Urban Identity in Central and Eastern Europe: The case of Lodz, Poland. European Urban and Regional Studies, 15(1). 53-70.

Zukin, S. (1995). The Cultures of cities. Malden and Oxford: Blackwell Publishers. 